胆囊摘出術後の病理検索にて診断された胆囊癌

$$
\text { に対する二期手術例の検討 }
$$

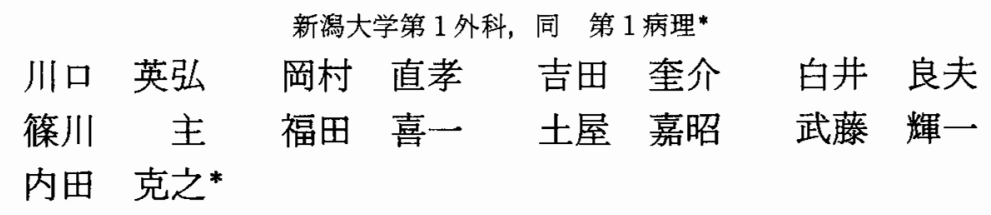

\title{
THE SECOND-STAGE OPERATION FOR GALLBLADDER CARCINOMA DIAGNOSED AT MICROSCOPIC EXAMINATION AFTER CHOLECYSTECTOMY
}

\author{
Hidehiro KAWAGUCHI, Naotaka OKAMURA, Keisuke YOSHIDA, \\ Yoshio SHIRAI, Mamoru SASAGAWA, Yoshikazu FUKUDA, \\ Yoshiaki TSUCHIYA, Terukazu MUTO and Katsuyuki UCHIDA*
}

1st Department of Surgery and Pathology*, Niigata University School of Medicine

\begin{abstract}
当科で経験した胆囊癌二期手術例10例を対象とし，二期手術の妥当性と選択すべき術式につき検討 した，腫瘍の主占居部位が胆震に限局（胆囊管非浸潤例）している深達度 ss 以上の進行癌症例（ 5 例） では, 胆袈摘出術に肝床・胆管切除+ 2 群リンパ節郭清を加えることで治療成績の向上が期待でさる あのと考光られたが, 胆囊管浸潤例（5例）では予後不良であり, 膵頭十二指腸切除十肝切除 +3 群 リンパ節郭清が適応されるべきと考兄られた。また手術侵襲の程度を一期手術例と比較したが，手術 時間・出血量・術後の経口摄取開始日・術後合併症・術後入院期間に招いては差は認められず，この 点からも積極的に二期手術を施行すべきであると考光られた。
\end{abstract}

索引用語：胆䘫癌二期手術, 胆囊摘出術十肝床・胆管切除 +2 群リンパ節郭清, 膵頭十二指腸切除十肝切除 +3 群リンパ節郭清

I.はじめに

胆囊摘出後の病理検索にて胆囊癌と診断される症例 は決してまれではない，われわれは，術中診断能の向 上の目的で 10 分間 $10 \%$ フォルマリン固定法の有用性を 強調してきだ2). しかしIIb 様病変や高度な胆囊炎合 併例では, 必ずしも診断が容易ではないのが現状であ る. 術後に診断された症例に対しては, 追加切除の必 要性があるか，またどのような術式を選択すべきかが 問題になるが, 今回, 自験例を分析し, 胆裹癌二期手 術の妥当性と選択すべき術式に関し検討したので報告 する.

\section{II. 自験例の概要と対象}

過去18年間に当科で経験した胆䨢癌手術例は112例

$<1988$ 年 1 月 13 日受理 >別刷請求先: 川口 英弘

T951 新潟市旭町通 1-754 新渴大学医学部第 1 外 科
で，切除例は55例[切除率 $49.1 \%$ ]，治㾤切除例は40例 〔治瘾切除率 $35.7 \%$ 〕であった。昭和 56 年以降, 肉眼的 深達度が固有等層までで明らかなりンパ節転移のない 症例に対し胆衰摘出術[以下胆摘]十肝床切除兼 2 群》 ンパ節郭清を基本術式とし, 腫湟の占居部位や深達度 およびリンパ節転移などの進展に応じ, 胆管合併切除, 膵頭十二指腸切除, 拡大肝右葉切除を加齐る段階的手 術適応を設定し実施してきだ3. また深達度の判定に 関しては，昭和56年以降では連続階段切片を用いて検 索した.

昭和56年以降の切除例は38例で，このうち二期手術 例10例を対象とし, 胆道癌取り扱い規約4) 亿従い, 腫瘍 の局在, 深達度, 進展様式, 術式ならびに初回手術か ら二期手術までの期間と予後につき分析し，あわせて 一期手術例や関連施設での二期手術非施行例19例とも 対比し検討した（表 1 ). 


\section{III. 成 績}

1）二期手術例の適応理由ならびに腫瘍占居部位,術 式, 進展様式と予後

二期手術を施行した理由は, (1)深達度 ss 以上の進行 癌であったため（9例)，(2)早期癌（m) ではあったが 胆囊管断端の切除縁に癌浸潤陽性であったため(1例) であった。二期手術施行後の検索結果は表 2 に示した が，腫煌の局在は胆霔内限局 5 例〔症例 $1-5$ ]，胆囊 管浸潤 5 例〔症例 6-10〕で, 2 例においては中部また は上部胆管むで浸潤していた。手術術式は肝床十胆管 切除術を 8 例に, また肝休切除術之胆管切除術を各 1 例に施行し, 全例に 2 群リンパ節郭清を行った。深達 度は m 1 例, ss 8 例, se 1 例で組織学的漿膜漫潤因子 はssをすべて $\mathrm{s}_{0}$ としたため $\mathrm{s}_{0} 9$ 例, $\mathrm{s}_{2} 1$ 例となった。 その他の進展様式は $\mathrm{n}_{1} 3$ 例 $〔 12 \mathrm{c}: 2$ 例， $12 \mathrm{c}+12 \mathrm{~b}_{2}$ ： 1 例], $\mathrm{n}_{2} 1$ 例 $[12 \mathrm{c}+8 \mathrm{a}], \operatorname{hinf}_{1} 1$ 例, $\operatorname{binf}_{2} 1$ 例で, 組 織学的進行度は stage I 5 例, II 2 例, III 3 例であっ た。初回の手術で切除縁に癌浸潤が疑われた症例は 9 例で $\mathrm{hw}_{1} 2$ 例[症例 2, 5], $\operatorname{hinf}_{2} 1$ 例[症例 3 ], bw 1 例〔症例 9 〕, $\mathrm{bW}_{2} 4$ 例〔症例 $\left.6,7,8,10\right], \mathrm{ew}_{2}$

表 1 対象

新潟大 1 外 (S. 44 61. 12)

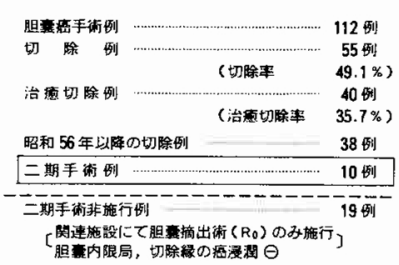

1 例〔症例 1]であったが, 二期手術の術中・術後の 病理検索で癌の残存を証明できたのは 4 例〔症例 1 ,

6，7，10]であった。症例 1 は Calot三角部に癌を 認め再切除にて切除縁の癌浸潤は陰性となった。しか 乙症例 6 と症例 7 では術中病理迅速でそれぞれ上部胆 管の切除縁の粘膜内と下部胆管側に癌浸潤を認めた が，症例 6 は腎癌を合併していたことまた症例 7 では 出血量と手術時間の関係加皇々以上の拡大手術は断 念せざるをえなかった。るな症例10では胆管側切除縁 の癌浸潤は陰性であったが, No 8a のリンパ節に転移 を認めた。予後は表 2 のごとくで胆囊内に限局の 5 例 は全例再発の北候なく生存中であったが，胆囊管浸潤 の 5 例中 3 例が癌死した。

2）初回手術から二期手術までの期間・進展形式なら びに予後と再発形式.

二期手術までの期間は 7 から94日までで，多くは 1 カ月程度 (34.7日 \pm 24.0 日, mean \pm SD) であったが, 特に予後之の間に一定の傾向は認められなかった。症 例 1 は $\mathrm{s}_{2} \mathrm{n}_{1}$ であっても 5 年 7 力月の現在生存中であ り, 症例 3 は94日目にまた症例 7 は43日目に手術した が，それぞれ $\operatorname{hinf}_{1}, \mathrm{n}_{1} \cdot \mathrm{bihf}_{2} \cdot \mathrm{bW}_{2}$ でも 2 年 9 力月と 2 年 8 力月の現在生存中である。しかし, 症例 8 のよ 5に，7日目に手術し stage Iであったにもかかわら ず，癌の腹腔内散布が原因と考兄られる再発により死 亡した症例子経験された。 また症例10は $\mathrm{n}_{2}(+)$ [No $8 \mathrm{a}]$ で, 術後 1 年目に再発死亡しており, 剖検は施行 できなかったが再入院時の computed tomography の 所見から No 14のリンパ節再発と判定した（表 3 ）.

表 2 胆襄癌二期手術例

新潟大 1 外（S. 56 61. 12）

\begin{tabular}{|c|c|c|c|c|c|c|c|c|c|c|c|c|c|}
\hline & & 年龃 & 性 & 占居部位 & 術 式 & $(R)$ & s & $\mathrm{n}$ & hinf & binf & stage & $w$ & $\begin{array}{c}\text { 予 後 } \\
\text { (S 62.2 現在) }\end{array}$ \\
\hline 1 & S.T. & 72 & $F$ & Gn & 肝床切除 & (2) & $\begin{array}{c}2 \\
(s e)\end{array}$ & 1 & 0 & 0 & III & 0 & 5 Y $7 \mathrm{M}$ （生） \\
\hline 2 & M.M. & 45 & $F$ & $G+b$ & 肝床・胆寛切除 & $(2)$ & $\begin{array}{c}0 \\
(s s)\end{array}$ & 0 & 0 & 0 & I & 0 & 4 Y $4 \mathrm{M}$ (生) \\
\hline 3 & N.S. & 69 & $F$ & Gfbn & " & (2) & $\begin{array}{c}0 \\
(s s)\end{array}$ & 0 & 1 & 0 & I] & 0 & 2 Y $9 M$ (生) \\
\hline 4 & w.S. & 62 & $M$ & Gf & * & $(2)$ & $\begin{array}{c}0 \\
\text { (ss) }\end{array}$ & 0 & 0 & 0 & 1 & 0 & 2 Y $2 M$ (生) \\
\hline 5 & H.Y. & 58 & $M$ & $\mathrm{~Gb}$ & 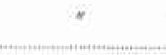 & (2) & $\begin{array}{c}0 \\
(\mathrm{ss})\end{array}$ & 0 & 0 & 0 & I & 0 & （生） \\
\hline 6 & Y.K. & 76 & $F$ & GnCGbfBms & $" \prime$ & $(2)$ & $\begin{array}{c}0 \\
(\mathrm{ss})\end{array}$ & 1 & 0 & 0 & I] & $\begin{array}{c}b_{2} \\
\text { (粘膜内) }\end{array}$ & 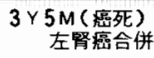 \\
\hline 7 & W.Y. & 74 & $M$ & GnCGbfBm & " & (2) & $\begin{array}{c}0 \\
(s s)\end{array}$ & 1 & 0 & 2 & II & bw2 & 2 Y $8 M$ (生) \\
\hline 8 & H.H. & 60 & $F$ & $\mathrm{GnC}$ & " & (2) & $\begin{array}{c}0 \\
(s s)\end{array}$ & 0 & 0 & 0 & 1 & 0 & (癌死) \\
\hline 9 & N.S. & 72 & $M$ & $\mathrm{GnC}$ & 胆管切除 & (2) & $\begin{array}{c}0 \\
(m)\end{array}$ & 0 & 0 & 0 & I & 0 & 1 Y $6 \mathrm{M}$ (生) \\
\hline 10 & M.T. & 66 & $\mathbf{F}$ & GnbfC & 肝床·胆管切除 & (2) & $\begin{array}{c}0 \\
(s s)\end{array}$ & 2 & 0 & 0 & 相 & 0 & (癌死) \\
\hline
\end{tabular}


表 3 胆峝癌二期手術例．初回手術から二期手術まで の期閪ならびに進展形式と予後

\begin{tabular}{|c|c|c|c|c|c|}
\hline & & $\begin{array}{l}\text { 期间 } \\
\text { (日) }\end{array}$ & 進展形式 & $\begin{array}{c}\text { 予 设 } \\
\text { (S62.2 牫在) }\end{array}$ & 死 因 \\
\hline 1 & S.T. & 16 & $s_{2}, n_{1}$ & $5 \times 7 M$ (生) & \\
\hline 2 & M.M. & 31 & & $4 \times 4 M$ (生) & \\
\hline 3 & N.S. & 94 & $\operatorname{hinf}_{1}$ & $2 \times 9 M \quad$ (生) & \\
\hline 4 & w.s. & 27 & & $2 Y 2 M$ （生） & \\
\hline 5 & H.Y. & 31 & & （生） & \\
\hline 6 & Y.K. & 41 & 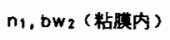 & $3 \times 5 M$ (癌死) & 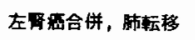 \\
\hline 7 & W.Y. & 43 & $n_{1}, \operatorname{binf} f_{2}, b w_{2}$ & $2 \vee 8 M$ (生) & \\
\hline 8 & H.H. & 7 & & $2 Y$ (和死) & 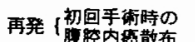 \\
\hline 9 & N.S. & 40 & & 1 Y $6 M$ （生） & \\
\hline 10 & M.T. & 17 & $n_{2}\left(N_{0} .8\right)$ & (禹死) & リンパ第再発 (Na. 14) \\
\hline
\end{tabular}

図 1 胆栾内限局進行胆变癌の生存率.二期手術施行 例 $\left(\mathrm{R}_{2}\right)$ 之非施行例 $\left(\mathrm{R}_{0}\right)$ の比較

(Kaplan-Meier 法)

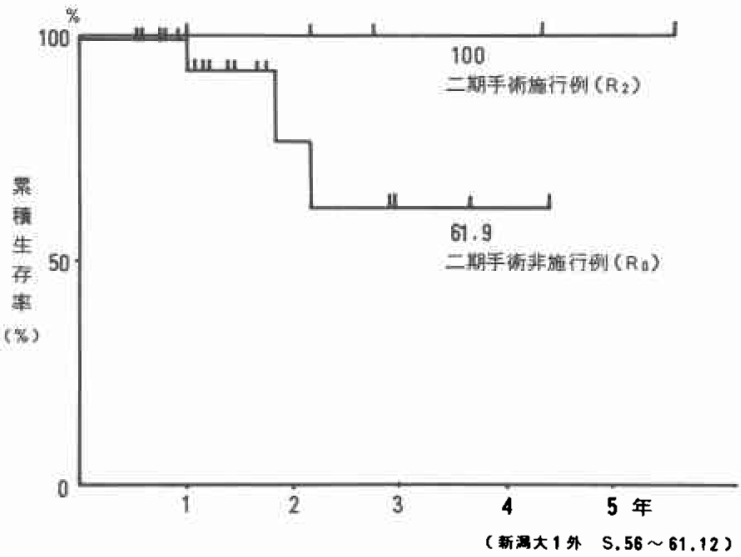

3）胆萎内限局進行胆衰癌における二期手術施行例 と非施行例の生存率の此較.

胆囊内に限局した深達度 ss 以上の進行胆亳癌中, 切 除縁の癌浸潤陰性例につき二期手術施行例と非施行例 の生存率を比較した. 非施行例では19例中 3 例が術後 1 ～ 2 年で再発死亡して扣り，3 年生存率は $61.9 \%$ で あった。これに対し二期手術例では，全例が生存中で あり再発の兆候は認めなかった（図 1 ）。

4）手術侵襲からみた一期・二期手術例の比較

二期手術の手術侵襲の程度をみる目的で, 胆摘十肝 床・胆管切除兼 2 群リンパ節郭清例につき，一期手術 例と対比し検討した。

二期手術例の手術時間は 5 時間30分〜11時間で, 8 例中 5 例が 5 時間台であり平均は約 6 時間30分（398 分土111分)であった.出血量は386〜 $3,468 \mathrm{ml}$ で平均は
表 4 胆要癌二期手術例. 胆摘十肝床・胆管切除 $\left(R_{2}\right)$ 施行の 8 例

新潟大 1 外（S. $56 \sim 61.12 ）$

\begin{tabular}{|c|c|c|c|c|c|c|}
\hline & & 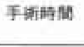 & $\underset{(\mathrm{m} \ell)}{\stackrel{\mathrm{w}}{\mathrm{m}})}$ & 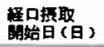 & 匍後合併症 & 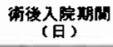 \\
\hline 1 & M.M. & $7^{\circ} 15^{\prime}$ & 1200 & 5 & $(-)$ & 29 \\
\hline 2 & N.S. & $5^{\circ} 48^{\prime}$ & 605 & 5 & $(-)$ & 36 \\
\hline 3 & w.s. & $5^{\circ} 42^{\prime}$ & 386 & 5 & $(\rightarrow)$ & 39 \\
\hline 4 & H.Y. & $6^{\circ} 12^{\prime}$ & 700 & 6 & 胆管炎 (疑) & 29 \\
\hline 5 & Y.K. & $5^{\circ} 55^{\prime}$ & 1233 & 7 & $(-)$ & 35 \\
\hline 6 & W.Y. & $11^{\circ} \mathrm{OO}^{\prime}$ & 3468 & 11 & $(-)$ & 61 \\
\hline 7 & H.H. & $5^{\circ} 30^{\prime}$ & & 8 & $(-)$ & 30 \\
\hline 8 & м.т. & $5^{\circ} 43^{\prime}$ & 900 & 5 & 剑悹染 & 59 \\
\hline r & $n \pm S D$ & $398^{\prime} \pm 111^{\prime}$ & $1213 \pm 1041$ & $6.5 \pm 2.1$ & & $39.8 \pm 13.0$ \\
\hline
\end{tabular}

表 5 胆变癌一期手術例. 胆摘十肝床・胆管切除 $\left(\mathbf{R}_{2}\right)$ 施行の 7 例

新潟大 1 外（S. 56 61. 12）

\begin{tabular}{|c|c|c|c|c|c|c|c|}
\hline & & 手術時的 & $\underset{(\mathrm{m} \ell)}{\text { 出血量 }}$ & 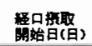 & 行後合件症 & 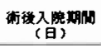 & 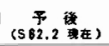 \\
\hline 1 & M.J. & $5^{\circ} 30^{\prime}$ & 680 & 6 & $(-)$ & 52 & AYB M (生) \\
\hline 2 & H.T. & $3^{\circ} 54^{\prime}$ & 600 & 5 & $\leftrightarrow$ & 56 & $10 \mathrm{M}$ (死) \\
\hline 3 & У.T. & $7^{\circ} 40^{\circ}$ & 1540 & 4 & $\Leftrightarrow$ & 10 & 3 Y5M (生) \\
\hline 4 & F.Y. & $7^{\circ} 40^{\circ}$ & 1155 & 5 & 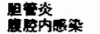 & 49 & $2 Y 1 M($ 生) \\
\hline 5 & s.s. & $5^{\circ} 50^{\prime}$ & 3523 & 9 & $(-)$ & 23 & 1 Y11M (生) \\
\hline 6 & S.H. & $7^{\circ} 38^{\prime}$ & 570 & 6 & $(-)$ & 29 & $9 M$ (生) \\
\hline 7 & N.M. & $6^{\circ} 34^{\prime}$ & 811 & 8 & $(-)$ & 27 & $3 M$ (生) \\
\hline me & \pm SD & $383.7^{\prime} \pm 85.3^{\prime}$ & $1268 \pm 1053.5$ & $6.1 \pm 1.8$ & & $39.4 \pm 13.3$ & \\
\hline
\end{tabular}

図 2 一期・二期手術例の比較, 胆摘十肝床 - 胆管切 除 $\left(R_{2}\right)$ 施行の15例

新潟大 1 外（S. 56 61. 12）

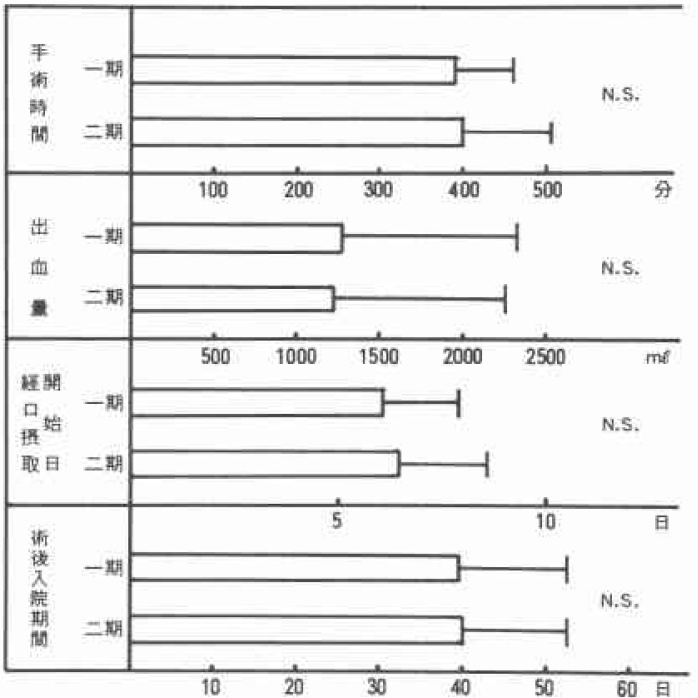

1,213士1,041ml であった. 術後の経口摄取開始日は 5 〜11日で平均は6.5土2.1日であった。術後合併症とし ては 1 例で軽度の胆管炎が疑われ，またも51例で創 
感染をみたが全身状態に大きな影響はなかった。術後 の入院期間は29 61日で 1 力月前後の症例が多く, 平 均は39.8土13.0日であった。症例 6 はその他の症例と 比べても手術時間・出血量・経口摂取開始日・術後入 院期間ともに不良で，この 1 例を除いた 7 例において は注济良好な結果であった（表４）。

これに対し一期手術例では，手術時間の平均は約 6 時間24分(383.7分士85.3分)で, 出血量 $1,268 \pm 1,053.5$ $\mathrm{ml}$, 経口摂取開始日6.1土1.8日, 術後入院期間 $39.4 \pm$ 13.3日であり，1例に術後合併症（胆管炎・腹腔内感 染)を認めた(表 5 ).

一期・二期手術例の手術時間・出血量・経口摄取開 始日・術後入院期間につき，T-testを用いて統計学的 有意差の検定を行ったが，いずれの項目においても差 は認めなかった（図 2)。

\section{IV. 考 察}

近年では各種画像診断技術の進歩は著しく，胆衰癌 の術前診断能む向上していることは周知の通りである が, 術前診断のついた症例は進行した症例が多いこと あ事実である.

Stage IVのように著しく進行した症例では（Sや Hinf 因子が Stage 決定因子となった一部の症例を除 いて）局所の対策では対応し難く，いくら拡大手術を 施行してもいまだ予後は不良であるといわざるをえな い。むしろ現時点では, Stage II ～III 症例の手術成績 をいかに向上させるかが，われわれ外科医に課せられ た最も重要な課題と考える.

胆石症や胆震炎を合併していない胆震隆起性病変に 対しては術前の超音波検查で診断可能となる場合が多 いが，これらを合併した場合術前診断す難しく，胆石 症や胆䨋炎の術前診断にて手術を施行されることが多 い.この際, 術中に診断することはきわめて重要であ り，われわれは胆囊癌の術中診断率向上をめざし切除 胆襄を $10 \%$ フォルマリンに10分間固定しその粘膜面を 検索することとしている，この操作である程度の術中 診断は可能であるが，IIb 様病変や高度な胆衰炎症例 では必ずしも診断は容易ではなく, 術後の病理学的検 索で胆囊癌の診断がつく場合も決してまれではない。 この様な症例の多くは Stage も I 〜IIIまでの場合が 多く, 的確な術式の適応により予後が期待される症例 が多く含まれているるのと考兄られ，これらの症例に 対しどの上うに対処するかによって胆霊癌の外科的治 療成績が左右されるといっても過言ではない，そこで この観点に立ち, 胆囊癌二期手術の妥当性と術式選択
上の問題点を検討した。

胆哓癌に対する二期手術の重要性を本邦で最初に提 唱したのは土屋ららであり，摘除胆囊を十分精查し，そ れが胆囊癌と判明すれば，たとえ早期癌であっても術 後 3 カ月以内に二期的桩大根治手術をなすべさであ

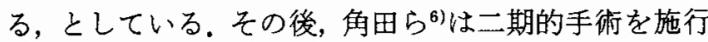
した 6 例を中心に検討し, 術中・術後に胆囊癌と判明 した症例に二期的手術を行らことは遠隔成績を向上さ せる1つの方法であり，深達度が “sm”以上であれば 二期手術の適応であるとしている。しかしこの“sm” そいう表現について，「胆囊は粘膜筋板を欠如するた め, 粘膜層 $(\mathrm{m})$ と筋層 $(\mathrm{pm})$ の中間型を便儀上 “ $\mathrm{sm}$ ” とした」，とのことである.

われわれは現在，二期手術の適応症例を“切除胆囊 の切除縁に癌浸潤がなくても深達度が $\mathrm{pm}$ 以上の症 例”之考えているが, 実際に pm 癌で二期手術を施行し た症例の経験はない，病理学的には $\mathrm{pm}$ 癌は早期癌と して报っているのになぜ pm 癌まで二期手術の対象と するかといら理由であるが，胆囊の全割標本で明らか に $\mathrm{pm}$ 癌と判定できる症例はきわめて少なく，今後こ の $\mathrm{pm}$ 癌を本当に早期癌として取り扱ってよいのかと いら問題を解決するためには確実な進展形式を把握す る必要があると考学ているためである。また一方，ss 癌を $\alpha, \beta, \gamma$ に分けてその進展形式を検討し，適応と する術式を区別しようとする試みもなされているが， これは今後の問題であ万う. 確かに ss 癌で胆摘のみで 終わった症例です予後の良好な症例むあることは事実 であり, 今回検討した二期手術非施行 ss 進行癌の19例 中 3 例は 3 年以上生存している.

今回検討した 10 例の二期手術例中 8 例が胆摘十肝 床・胆管切除兼 2 群リンパ節郭清であり，この術式を 基本術式とした場合主占居部位が胆囊に限局した症例 (胆旁管非浸潤例)の予後は良好である。しかしこの胆 震に限局した 5 例中 3 例は結果的に stage Iであり， おとらく二期手術を施行しなかったとしても生存期間 には差がでなかったものと推測されたが，その他の 2 例は stage III とII 各 1 例でそれぞれ 5 年 7 カ月, 2 年 9 カ月生存しており二期手術により延命効果があった ものと考えている. しかし， $\mathrm{s}_{0}(\mathrm{pm}), \mathrm{n}_{0}, \operatorname{hinf}_{0}, \mathrm{~b}_{0}$, stage I で 6 年 2 カ月生存中であると角田ら ${ }^{6}$ が報告し た症例は 7 年 5 カ月で局所再発にて死亡して招り7), 深達度 pm の診断が全割切片によったかどうかに多少 の疑問は残るものの,たとえ一部に ss 以上の部があっ たとしても 5 年以上の経過後に再発死亡する症例が存 
在することからすると術式の根治性を論ずる場合慎重 でなければならないと反省させられる。

一方, 占居部位が胆裹管にかかっていたり胆管に浸 潤していた症例の予後はけっして满足できるものでは なく，以前の報告3でも指摘したようにリンパ節転移 や傍神経侵襲などの間質浸潤も著明であり, 胆摘十肝 床・胆管切除兼 2 群リンパ節郭清では延命効果に限界 があり, 膵頭十二指腸切除十肝切除兼 3 群リンパ節郭 清を適応とすべきと考兄られた。

胆囊癌に対する膵頭十二指腸切除術の適応には議論

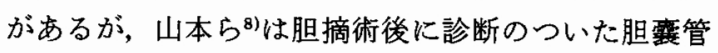
浸潤例に対し膵頭十二指腸切除術を加え, No 13a リン パ節転移陽性にもかかわらず術後 1 年までに再発の兆 候が認められなかったため，この術式による再切除が 有意義であったと報告している。術後 1 年程度の生存 期間では術式の妥当性を論ずるには不十分であるが, われわれる一期手術例ではあるが, No 13a のリンパ節 に転移陽性であったため膵頭十二指腸切除十肝床切除 を加克, 術後 3 年 6 カ月経過した現在生存中の症例を 経験している. 山本らは積極的手術にもかかわらず stage II・III 3 年生存率が $30 \%$ 前後9)であるところか ら, 成績改善のために占居部位が $\mathrm{Gn} や \mathrm{Gfb}$ の症例ま たはNo 12 リンハ節転移陽性例に対し膵頭十二指腸切 除十肝切除を商応としている. stage II, III こそ外科 治療による永久治癒の可能性を追及すべき領域であ り，切除範囲の拡大だけでなく可及的な en blok の郭 清操作により根治性の向上を目指すことが必要と考え ており, 当科での 3 年生存率は stage II $90 \%$, III $53 \%{ }^{10)}$ である.しかし胆囊管浸潤例の手術成績は不良であり, 膵頭十二指腸切除十肝切除兼 3 群リンパ節郭清を加兄 ることで多少なりとも予後の向上が期待できるものと 思われる。

二期手術例は文献上長崎大学第 2 外科と東京女子医 科大学消化器病せンターの各 6 例が報告されている が，われわれの10例が本邦で最も多いものと思われる. 実際に二期手術を実施する上での重要な問題は, いか に患者に再手術の必要性を説明して予解をらるかとい ら点である. 今回対象とした 10 例のらち初回手術が当 科で施行された症例は 4 例であるが，やはり“切除胆 衰の病理検索では一部に悪性化の傾向を疑わせる所見 がみられるので再手術して精查する必要がある”之説 明している：他施設での初回手術例にも適応症例が多 いことを考兄ると病理学教室との密な連携や過去 6 年 間継続している関連施設の内科・外科・放射線科・病
理を含めての胆道疾患月例会の役割も重要である。ま た二期手術の必要性を患者に説明するに当たり，われ われ外科医自身が真にその必要性を確信していること が患者やその家族の心を動かするのと痛感している。

また手術侵襲の程度を再認識する目的で同一術式に つき一期手術と比較したが，手術時間・出血量・術後 の経口摂取開始日・術後合併症・術後入院期間におい ては差を認めなかった，手術時間に差がでなかった理 由としては，一期手術では癌の進展範用の把握と術中 病理検索などのために，また二期では再手術による癒 着剥離のために時間を要したためと考えられた。

以上の検討結果からみた場合，いまだ当科における 二期手術例の経過観察期間は短く断定することはまだ 危険かもしれないが，少なくとも現時点での成績から すると一期・二期手術間には手術侵襲上差はなく，積 極的に二期手術を施行することは胆囊癌の治療成績向 上の面で意味あるものと考穴られた。

\section{V. 結 語}

当科で経験した胆震癌二期手術例10例を対象とし二 期手術の妥当性と選択すべき術式につき検討し次の結 果を得た。

（1）腫煌の主占居部位が胆囊に限局（胆囊管非浸潤 例) している深達度 ss 以上の進行癌症例では, 胆霊摘 出術に肝床・胆管切除 +2 群リンパ節郭清を加学るこ とで予後の向上が期待できるすのと考光られたが，胆 震管浸潤例ではこれによって子予後不良であり，さら に脺頭十二指腸切除十肝切除+3 群リンパ節郭清が適 応されるべきと考觉られた。

（2）手術侵襲の程度を一期手術例と比較したが，手 術時間・出血量・術後の释口摄取開始日・術後合併症・ 術後入院期間においては差は認められず，この点から も積極的に二期手術を施行すべきであると考学られ た。

\section{文献}

1）渡辺英伸, 鬼島 宏, 内田克之㳗加: 早期胆縟癌の 定義と病理形態学的特徵. 胃と腸 $21: 483-495$, 1986

2）鬼島 宏, 渡辺英伸, 白井良夫潘加: 胆震癌の臨床 病理一とくに早期胆篦癌について一. 消外 8: 403-411, 1985

3）川口英弘, 吉田奎介, 武藤輝一ほか：術中・術後に 偶然発見された胆要癌に対する治療.消外 8 : $443-451,1985$

4) 日本胆道外科研究会編：外科・病理胆道癌取扱兄 規約．第 2 版。金原出版，東京， 1986 
5）土屋凉一，赤司光弘：胆票癌の外科的治療一とく に 2 期的扗大根治手術について一. 日消外会誌 $9: 193-198,1976$

6）角田 司, 元島幸一, 土屋凉一：胆荎癌の治療一胆 変癌の二期的手術. 胆と膵 $4: 1243-1250,1983$

7) 江藤敏文, 土屋凉一, 原田 昇ほか：胆道癌長期生 存例一特に治告切除後 3 年以上経過後死率例 と非 治虑切除長期生存例の検討. 日消外会誌 21 ：
201, 1988

8）山本雅一, 高橋 健, 吉川達也ほか：膵頭十二指腸 切除による再切除がきわめて有意義であった胆竞 癌の 1 例. 胆と膡 $8: 93-97,1987$

9）羽生富士夫, 吉川達也, 粱 英樹 : 胆焉䙖の進展様 式からみた手術術式. 胆と腈 $8: 123-131,1987$

10）川口英弘, 吉田桂介, 白井良夫はか：胆等癌長期生 存例の検討. 胆と膆 $8: 1187-1195,1987$ 